\title{
Correction to: Is there a social gradient in how youth with mental disorder perform academically? Findings from a Swedish longitudinal register-based study
}

Evelina Landstedt ${ }^{1,2,3^{*}}$, Cristian Bortes ${ }^{2}$ and Mattias Strandh ${ }^{2}$

Correction to: BMC Psychiatry 21, 441 (2021)

https://doi.org/10.1186/s12888-021-03448-z

Following publication of the original article [1], the author reported that the Abstract was missing in the published article.

The original article [1] has been corrected.

\section{Author details}

'Department of Social and Psychological Studies, Karlstad University, Universitetsgatan 2, SE-651 88 Karlstad, Sweden. '2Department of Social Work, Umeå University, SE-907 87 Umeå, Sweden. ${ }^{3}$ Centre for Research on Child and Adolescent Mental Health, Karlstad University, SE-651 88 Karlstad, Sweden

Published online: 17 September 2021

\section{Reference}

1. Landstedt, et al. Is there a social gradient in how youth with mental disorder perform academically? Findings from a Swedish longitudinal register-based study. BMC Psychiatry. 2021;21:441. https://doi.org/10.1186/ s12888-021-03448-z.

\footnotetext{
The original article can be found online at https://doi.org/10.1186/s12888021-03448-z.

* Correspondence: evelina.landstedt@kau.se

${ }^{1}$ Department of Social and Psychological Studies, Karlstad University,

Universitetsgatan 2, SE-651 88 Karlstad, Sweden

2Department of Social Work, Umeå University, SE-907 87 Umeå, Sweden

Full list of author information is available at the end of the article
}

(c) The Author(s). 2021 Open Access This article is licensed under a Creative Commons Attribution 4.0 International License, which permits use, sharing, adaptation, distribution and reproduction in any medium or format, as long as you give appropriate credit to the original author(s) and the source, provide a link to the Creative Commons licence, and indicate if changes were made. The images or other third party material in this article are included in the article's Creative Commons licence, unless indicated otherwise in a credit line to the material. If material is not included in the article's Creative Commons licence and your intended use is not permitted by statutory regulation or exceeds the permitted use, you will need to obtain permission directly from the copyright holder. To view a copy of this licence, visit http://creativecommons.org/licenses/by/4.0/. The Creative Commons Public Domain Dedication waiver (http://creativecommons.org/publicdomain/zero/1.0/) applies to the data made available in this article, unless otherwise stated in a credit line to the data. 